\title{
NOTES \\ DNA Relatedness among Aeromonas allosaccharophila Strains and DNA Hybridization Groups of the Genus Aeromonas
}

\author{
CONSUELO ESTEVE, ${ }^{1,2 *}$ M. CARMEN GUTIÉRREZ, ${ }^{2}$ AND ANTONIO VENTOSA ${ }^{2}$ \\ Departamento de Microbiología y Ecología, Facultad de Ciencias Biológicas, Universitat de València, \\ E-46100 Burjasot (Valencia), ${ }^{1}$ and Departamento de Microbiología y Parasitología, \\ Facultad de Farmacia, Universidad de Sevilla, E-41012 Seville, ${ }^{2}$ Spain
}

\begin{abstract}
The genomic relatedness among three Aeromonas allosaccharophila strains, including the type strain, and other Aeromonas type and reference strains that were assigned to DNA hybridization groups was estimated by DNA-DNA hybridization (competition procedure using a membrane method). All $A$. allosaccharophila strains were highly related $(70$ to $100 \%)$ to strains $289^{\mathrm{T}}\left(=\mathrm{CECT} 4199^{\mathrm{T}}\right)$ and ATCC 35942. Type strains of other validated Aeromonas species, reference strains of DNA groups 8 and 11, and the Aeromonas sp. strain ATCC 43946 (enteric group 501) were 0 to $41 \%$ related to $A$. allosaccharophila $289^{\mathrm{T}}$ and ATCC 35942 . The G+Cs content of $A$. allosaccharophila strains were in the range 55.9 to $57.3 \mathrm{~mol} \%$. The $\mathrm{G}+\mathrm{C}$ content of the type strain of this species was $\mathbf{5 6 . 9} \mathrm{mol} \%$, a value somewhat lower than that reported in the original description.
\end{abstract}

Kluyver and van Niel (13) proposed the genus Aeromonas to accommodate enteric bacterium-like microorganisms that are motile by means of polar flagella. In the first edition of Bergey's Manual of Systematic Bacteriology (2), this genus was included in the family Vibrionaceae. At present, the proposal to place the genus Aeromonas in the new family Aeromonadaceae (5), which was based on molecular genetic data, has been recently validated (11). Moreover, the evidence that the genus Aeromonas includes 13 DNA homology groups $(4,7,9,21)$ and the recent description of six new mesophilic Aeromonas species derived mainly from these DNA relatedness data $(1,3,4,9,10$, 22) have significantly changed Popoff's taxonomy of the genus Aeromonas (20). On the other hand, results obtained from $16 \mathrm{~S}$ ribosomal DNA sequencing studies have reported indistinguishable 16S rRNA gene sequences for well-defined genospecies that are based on DNA-DNA reassociation studies, suggesting a lack of sensitivity of rRNA sequencing in separating very closely related species (16). Recently, Martínez-Murcia and colleagues (17) proposed the new species, Aeromonas allosaccharophila, to accommodate mesophilic Aeromonas strains which had a unique phenotypic profile (6) and on the basis of 16S rRNA gene sequence analysis represented an unknown genetic line within the genus Aeromonas (17). However, DNA hybridization studies were not carried out with the $A$. allosaccharophila strains. Thus, the genetic relatedness of this species within the genus Aeromonas was not determined. In the present paper we report the results of a DNA-DNA hybridization study comparing $A$. allosaccharophila $289^{\mathrm{T}}$ (= CECT $4199^{\mathrm{T}}$ ) and ATCC 35942 with other strains of $A$. al losaccharophila and other Aeromonas species, as well as the DNA base composition of all $A$. allosaccharophila strains.

A. allosaccharophila strains $\left(289^{\mathrm{T}}, 290\right.$, and ATCC 35942) and Aeromonas and Escherichia strains used as references (see Tables 1 and 2) were grown in tryptone broth (1\% [wt/vol] tryptone [Oxoid], $1 \%$ [wt/vol] $\mathrm{NaCl} ; \mathrm{pH} 7.2$ ) at $25^{\circ} \mathrm{C}$, and cells were harvested in late exponential phase. DNA was extracted and purified by the method of Marmur (14), and its purity was

\footnotetext{
${ }^{*}$ Corresponding author. Mailing address: Departamento de Microbiología y Ecología, Facultad de Ciencias Biológicas, Universitat de València, E-46100 Burjasot (Valencia), Spain.
}

assessed from the $E_{260} / E_{280}$ and $E_{230} / E_{260}$ ratios (12). The $\mathrm{G}+\mathrm{C}$ content of the DNA was determined from the midpoint value $\left(T_{m}\right)$ of the thermal denaturation profile $(15)$ obtained with a Perkin-Elmer UV-Vis 551S spectrophotometer at 260 $\mathrm{nm}$. This instrument was programmed for temperature increases of $1.0^{\circ} \mathrm{C} / \mathrm{min}$. The $T_{m}$ was determined by a graphic method previously described ( 8 ), and the $G+C$ content was calculated from this temperature by using the equation of Owen and Hill (18) in $0.1 \times$ standard SSC $(1 \times$ SSC is $0.15 \mathrm{M}$ $\mathrm{NaCl}$ plus $0.015 \mathrm{M}$ sodium citrate). The $T_{m}$ of DNA from Escherichia coli NCTC 9001 was taken as a reference (see Table 1). DNA-DNA hybridization was conducted in triplicate by the competition procedure with the membrane method described by Johnson (12). DNAs from strains $289^{\mathrm{T}}$ and ATCC 35942 were nick translated with $\left[{ }^{3} \mathrm{H}\right] \mathrm{dCTP}$ (RPN 1601Y; Amersham International, Amersham, United Kingdom) and reacted with unlabeled competitor DNAs from the other Aeromonas strains at a reassociation temperature of $54^{\circ} \mathrm{C}$. This hybridization temperature was selected according to the $T_{m}$ of the DNA used as a labeled probe (12). The hybridization mixtures contained $30 \%$ formamide (Sigma). The ratio of the concentrations of competitor to labeled DNA was at least 150:1. After hybridization, the filters were washed in $2 \times \mathrm{SSC}$ at the optimal renaturation temperature $\left(54^{\circ} \mathrm{C}\right)$. The radioactivity

TABLE 1. $T_{m} \mathrm{~s}$ and DNA base compositions of $A$. allosaccharophila strains and $E$. coli NCTC 9001

\begin{tabular}{lccc}
\hline & $\begin{array}{c}\text { Mean } T_{m}{ }^{a} \\
\left({ }^{\circ} \mathrm{C}\right)\end{array}$ & \multicolumn{2}{c}{$\begin{array}{c}\mathrm{G}+\mathrm{C} \text { content (mol\%) } \\
\text { determined }\end{array}$} \\
\cline { 3 - 4 } & & $\begin{array}{c}\text { In this } \\
\text { study }\end{array}$ & $\begin{array}{c}\text { Elsewhere } \\
\text { (reference) }\end{array}$ \\
\hline A. allosaccharophila & & & \\
$289^{\mathrm{T}}$ (= CECT $\left.4199^{\mathrm{T}}\right)$ & $77.5 \pm 0.4$ & 56.9 & $59.5(18)$ \\
290 & $77.0 \pm 0.0$ & 55.9 & $\mathrm{ND}$ \\
ATCC 35942 & $77.7 \pm 0.4$ & 57.3 & $\mathrm{ND}$ \\
E. coli NCTC 9001 & $74.6 \pm 0.05^{c}$ & 50.9 & $50.9(20)$ \\
\hline
\end{tabular}

${ }^{a}$ Values are averages of three or more separate determinations in $0.1 \times$ SSC buffer.

${ }_{b}^{b} \mathrm{ND}$, not determined.

${ }^{c}$ The $T_{m}$ reported elsewhere is $74.6^{\circ} \mathrm{C}(20)$. 
TABLE 2. Levels of DNA-DNA homology between A. allosaccharophila strains and other Aeromonas species and strains

\begin{tabular}{|c|c|c|}
\hline \multirow{2}{*}{ Source of unlabeled DNA } & \multicolumn{2}{|c|}{$\begin{array}{l}\text { \% Homology }{ }^{a} \text { with } \\
{ }^{3} \text { H-labeled DNA } \\
\text { from: }\end{array}$} \\
\hline & $\begin{array}{c}289^{\mathrm{T}} \\
(=\mathrm{CECT} \\
\left.4199^{\mathrm{T}}\right)\end{array}$ & $\begin{array}{l}\text { ATCC } \\
35942\end{array}$ \\
\hline \multicolumn{3}{|l|}{ A. allosaccharophila } \\
\hline $289^{\mathrm{T}}\left(=\right.$ CECT $\left.4199^{\mathrm{T}}\right)$ & 100 & 94 \\
\hline 290 & 100 & 94 \\
\hline ATCC 35942 & 70 & 100 \\
\hline A. hydrophila ATCC $7966^{\mathrm{T}}$ (DNA group 1) & ND & 0 \\
\hline \multicolumn{3}{|l|}{ A. salmonicida subsp. salmonicida (DNA group 3) } \\
\hline NCIMB $1102^{\mathrm{T}}$ & 0 & 33 \\
\hline ATCC 14174 & 0 & 1 \\
\hline A. caviae ATCC $15468^{\mathrm{T}}$ (DNA group 4 ) & 0 & 41 \\
\hline A. media ATCC $33907^{\mathrm{T}}$ (DNA group $5 \mathrm{~b}$ ) & 35 & 0 \\
\hline A. eucrenophila NCIMB $74^{\mathrm{T}}$ (DNA group 6) & 22 & 0 \\
\hline A. sobria CIP $74.33^{\mathrm{T}}$ (DNA group 7 ) & 0 & 36 \\
\hline $\begin{array}{l}\text { A. veronii biogroup sobria ATCC } 9071 \text { (DNA group } \\
\text { 8/10) }\end{array}$ & 0 & 40 \\
\hline $\begin{array}{l}\text { A. veronii biogroup veronii ATCC } 35624^{\mathrm{T}} \text { (DNA } \\
\text { group } 8 / 10 \text { ) }\end{array}$ & 0 & 0 \\
\hline A. jandaei ATCC $49568^{\mathrm{T}}$ (DNA group 9) & 0 & 13 \\
\hline Aeromonas sp. strain ATCC 35941 (DNA group 11) & 0 & 11 \\
\hline A. schubertii ATCC $43700^{\mathrm{T}}$ (DNA group 12) & 0 & 0 \\
\hline A. trota ATCC $49657^{\mathrm{T}}$ (DNA group 13) & 0 & 0 \\
\hline Aeromonas sp. strain ATCC 43946 (enteric group 501) & 0 & 0 \\
\hline A. ichthiosmia DSM $6393^{\mathrm{T}}$ & 0 & 0 \\
\hline A. enteropelogenes DSM $6394^{\mathrm{T}}$ & ND & 21 \\
\hline
\end{tabular}

${ }^{a}$ Each value is the mean from at least two independent experiments done in triplicate. ND, not determined.

bound to the filters was measured in a liquid scintillation counter (Beckman Instruments, Inc.), and the percentage of reassociation was calculated as described previously (12).

The $\mathrm{G}+\mathrm{C}$ content of $A$. allosaccharophila $289^{\mathrm{T}}$ (= CECT $4199^{\mathrm{T}}$ ) was $56.9 \mathrm{~mol} \%$, which is different from that previously described (17) (Table 1). This value, however, was very close to those determined for other $A$. allosaccharophila strains (Table 1). Thus, the $\mathrm{G}+\mathrm{C}$ contents of the strains of $A$. allosaccharophila were between 55.9 and $57.3 \mathrm{~mol} \%$ (Table 1). Interestingly, $A$. allosaccharophila presented a very characteristic $\mathrm{G}+\mathrm{C}$ content compared with the values reported for the other mesophilic Aeromonas species, which are generally $\geq 58 \mathrm{~mol} \%(3,4,9,10,21,22-24)$.

The DNA homology values obtained between two representatives of $A$. allosaccharophila and all strains investigated are shown in Table 2. A. allosaccharophila $289^{\mathrm{T}}\left(=\mathrm{CECT} 4199^{\mathrm{T}}\right)$ showed $70 \%$ or more DNA relatedness with the other $A$. allosaccharophila strains. Nevertheless, very low levels of homology ( 0 to $35 \%$ ) were obtained between this strain and the reference strains studied, representing psychrophilic and mesophilic species and representatives of DNA homology groups of the genus Aeromonas (Table 2). Similar results (0 to $41 \%$ hybridization) were obtained when labeled DNA from $A$. allosaccharophila ATCC 35942 was used as a reference (Table 2). Therefore, our results clearly confirm that the strains $289^{\mathrm{T}}$ $\left(=\right.$ CECT $\left.4199^{\mathrm{T}}\right), 290$, and ATCC 35942 constitute a very homogeneous group genotypically, showing DNA reassociation levels $(\geq 70 \%)$ consistent with the currently accepted genospecies concept $(19,25)$. Likewise, these data support the hypothesis that the species $A$. allosaccharophila represents a new hybridization group of the genus Aeromonas. Tentatively, we propose to define this new hybridization group as group 14 .
C. Esteve thanks the Conselleria de Cultura (Generalitat Valenciana) for her postdoctoral research fellowship. This work has been partially supported by grants from the Ministerio de Educación y Ciencia (Dirección General de Investigación Cientifica y Técnica, PB92-0670 and PB93-0920) and from the Junta de Andalucía.

\section{REFERENCES}

1. Allen, D. A., B. Austin, and R. R. Colwell. 1983. Aeromonas media, a new species isolated from river water. Int. J. Syst. Bacteriol. 33:599-604.

2. Baumann, P., and R. H. W. Schubert. 1984. Vibrionaceae, p. 516-549. In N. R. Krieg and J. G. Holt (ed.), Bergey's manual of systematic bacteriology, vol. 1. The Williams \& Wilkins Co., Baltimore.

3. Carnahan, A., G. R. Fanning, and S. W. Joseph. 1991. Aeromonas jandaei (formerly genospecies DNA group $9 A$. sobria), a new sucrose-negative species isolated from clinical specimens. J. Clin. Microbiol. 29:560-564.

4. Carnahan, A. M., T. Chakraborty, G. R. Fanning, D. Verma, A. Ali, J. M. Janda, and S. W. Joseph. 1991. Aeromonas trota sp. nov., an ampicillin-susceptible species isolated from clinical specimens. J. Clin. Microbiol. 29:1206-1210.

5. Colwell, R. R., M. T. MacDonell, and J. de Ley. 1986. Proposal to recognize the family Aeromonadaceae fam. nov. Int. J. Syst. Bacteriol. 36:473-477.

6. Esteve, C., and E. Garay. 1992. Numerical taxonomy of Vibrionaceae and Aeromonadaceae strains from water and fish, p. 33-36. In J. Schindler (ed.) Proceedings of the conference on taxonomy and automated identification of bacteria. Czech Society for Microbiology, Prague.

7. Fanning, G. R., F. W. Hickman-Brenner, J. J. Farmer III, and D. J. Brenner. 1985. DNA relatedness and phenotypic analysis of the genus Aeromonas, p. 319, abstr. C-116. In Proceedings of the Annual Meeting of the American Society for Microbiology. American Society for Microbiology, Washington, D.C.

8. Ferragut, C., and H. Leclerc. 1976. Étude comparative des méthodes de détermination du Tm de l'ADN bactérien. Ann. Microbiol. 127:223-235.

9. Hickman-Brenner, F. W., G. R. Fanning, M. J. Arduino, D. J. Brenner, and J. J. Farmer III. 1988. Aeromonas schubertii, a new mannitol-negative species found in human clinical specimens. J. Clin. Microbiol. 26:1561-1564.

10. Hickman-Brenner, F. W., K. L. MacDonald, A. G. Steigerwalt, G. R. Fanning, D. J. Brenner, and J. J. Farmer III. 1987. Aeromonas veronii, a new ornithine decarboxylase-positive species that may cause diarrhea. J. Clin. Microbiol. 25:900-906.

11. International Committee on Systematic Bacteriology Subcommittee on the Taxonomy of Vibrionaceae. 1992. Minutes of the meetings, 18 and 20 September 1990, Osaka, Japan. Int. J. Syst. Bacteriol. 42:199-201.

12. Johnson, J. L. 1994. Similarity analysis of DNAs, p. 655-682. In P. Gerhardt R. G. E. Murray, W. A. Wood, and N. R. Krieg (ed.), Methods for general and molecular bacteriology. American Society for Microbiology, Washington, D.C.

13. Kluyver, A. J., and C. B. van Niel. 1936. Prospects for a natural system of classification of bacteria. Zentralbl. Bakteriol. Parasitenkd. Infektionskr. Hyg. Abt. 1 Orig. 94:369-403.

14. Marmur, J. 1961. A procedure for the isolation of deoxyribonucleic acid from microorganisms. J. Mol. Biol. 3:208-218.

15. Marmur, J., and P. Doty. 1962. Determination of the base composition of deoxyribonucleic acid from its thermal denaturation temperature. J. Mol. Biol. 5:109-118.

16. Martínez-Murcia, A. J., S. Benlloch, and M. D. Collins. 1992. Phylogenetic interrelationships of members of the genera Aeromonas and Plesiomonas as determined by $16 \mathrm{~S}$ ribosomal DNA sequencing: lack of congruence with results of DNA-DNA hybridizations. Int. J. Syst. Bacteriol. 42:412-421.

17. Martínez-Murcia, A. J., C. Esteve, E. Garay, and M. D. Collins. 1992. Aeromonas allosaccharophila sp. nov., a new mesophilic member of the genus Aeromonas. FEMS Microbiol. Lett. 91:199-206.

18. Owen, R. J., and L. R. Hill. 1979. The estimation of base compositions, base pairing and genome size of bacterial deoxyribonucleic acids, p. 217-298. In F. A. Skinner and D. W. Lovelock (ed.), Identification methods for microbiologists, 2nd ed. Academic Press Ltd., London.

19. Owen, R. J., and D. Pitcher. 1985. Current methods for estimating DNA base composition and levels of DNA-DNA hybridization, p. 67-93. In M. Goodfellow and E. Minnikin (ed.), Chemical methods in bacterial systematics. Academic Press Ltd., London.

20. Popoff, M. 1984. Genus III. Aeromonas Kluyver and van Niel 1936, $398^{\text {AL }}$, p. 545-548. In N. R. Krieg and J. G. Holt (ed.), Bergey's manual of systematic bacteriology, vol. 1. The Williams \& Wilkins Co., Baltimore.

21. Popoff, M. Y., C. Coynault, M. Kiredjian, and M. Lemelin. 1981. Polynucleotide sequence relatedness among motile Aeromonas species. Curr. Microbiol 5:109-114.

22. Schubert, R. H.W, and M. Hegazi. 1988. Aeromonas eucrenophila species nova and Aeromonas caviae, a later and illegitimate synonym of Aeromonas punctata. Zentralbl. Bakteriol. Parasitenkd. Infektionskr. Hyg. Abt. 1 Orig. Reihe A 268:34-39.

23. Schubert, R. H. W., M. Hegazi, and W. Wahling. 1990. Aeromonas enteropelogenes species nova. Hyg. Med. 15:471-472.

24. Schubert, R. H. W., M. Hegazi, and W. Wahling. 1990. Aeromonas ichthiosmia species nova. Hyg. Med. 15:477-479.

25. Wayne, L. G., D. J. Brenner, R. R. Colwell, P. A. D. Grimont, O. Kandler, M. I. Krichevsky, L. H. Moore, W. E. C. Moore, R. G. E. Murray, E. Stackebrandt, M. P. Starr, and H. G. Trüper. 1987. Report of the Ad Hoc Committee on Reconciliation of Approaches to Bacterial Systematics. Int. J. Syst. Bacteriol. 37:463-464. 